\title{
A Strategy to Identify Genes Associated with Circulating Solid Tumor Cell Survival in Peripheral Blood
}

\author{
Marcia V. Fournier, ${ }^{1}$ Maria da Gloria Costa Carvalho, ${ }^{2}$ and \\ Arthur B. Pardee ${ }^{1}$ \\ ${ }^{1}$ Cancer Biology Division, Dana-Farber Cancer Institute, Boston, \\ Massachusetts, U.S.A. \\ ${ }^{2}$ Laboratory of Control of Gene Expression, Instituto de Biofisica \\ Carlos Chagas Filho and Laboratory of Molecular Oncology, Hospital \\ Universitario Clementino Fraga Filho, Universidade Federal do Rio de \\ Janeiro, Rio de Janeiro, Brazil
}

Communicated by A. Pardee. Accepted March 24, 1999.

\begin{abstract}
Efforts in metastasis research have centered on the phenotypic and genetic differences between primary site and metastatic site tumors. However, genes that may be used as molecular markers of metastasis in circulating tumor cells remain unidentified. Genes regulating the dissemination and survival of solid tumor cells in the blood, as well as their adaptation to new environments, could be candidates for unique metastatic tumor markers. Differential display (DD) was conducted to compare the blood of tumor-free individuals with the blood of patients with lung, breast, and colon cancers. Twenty-one up-expressed genes in the tumor patient blood samples but
\end{abstract}

none in the tumor-free donor blood samples were identified. Nine of these samples were isolated, amplified, and directly sequenced. A gene AB-1 homologous to a $\mathrm{Bcl}-2$ family member, which might function as an apoptosis inhibitor, was identified. The overexpression of an apoptosis inhibitor in blood from patients with metastatic tumors might be correlated with the capability of solid tumor cells to survive in peripheral blood. This is the first demonstration of the usefulness of comparing control and patient blood samples by DD to find novel potential genetic markers identifying metastasis in the blood.

\section{Introduction}

Cancer recurrence and metastasis continue to pose major problems in clinical management (1). Advances in diagnostic techniques and technology may allow cancer detection at earlier stages, when the tumor burden is smaller and potentially more curable. The relationship between circulating tumor cells and the development of secondary disease is not fully understood and a

Correspondence and reprint requests to: Dr. Marcia V. Fournier, Cancer Biology Division, Dana-Farber Cancer Institute, Boston, MA 02115, U.S.A. Phone: 617-632-4683; Fax: 617-632-4680; E-mail: fournier@mbcrr.harvard.edu method to detect small numbers of such cells may provide a tool with which to evaluate their role in the disease process. However, very little is known about the molecular mechanism that regulates circulating tumor cells' survival and metastasis. Genes regulating the dissemination and survival of solid tumor cells in the blood, as well as their adaptation to new environments, could be candidates for unique metastatic tumor markers.

Systemic spread of tumor cells in peripheral blood is an essential step for hematogenous metastasis (2). The vast majority of tumor cells that enter the circulation are rapidly elim- 
inated by factors such as blood turbulence (3), natural killer cells (4), and macrophages (5). Nitric oxide secretion by activated macrophages and endothelial cells is a major cytotoxic mediator responsible for the destruction of tumor cells passing through capillary beds (6). In addition, activation of apoptosis also contributes to eliminate metastatic cells $(7,8)$. In contrast, fibrin deposits, platelet aggregation, and adhesion around the tumor emboli may protect circulating cells from mechanical trauma, facilitate their arrest in capillary beds, and protect tumor emboli from destruction by host immunity (9).

To find novel genetic markers for solid tumor cells circulating in blood, differential display (DD) (10) was conducted to compare RNA isolated from the blood of tumor-free individuals with RNA from the blood of patients with lung, breast, and colon cancers.

\section{Materials and Methods}

Patients' Samples

Eleven blood samples from patients with histologically documented nonhematological cancer, with either localized or metastatic disease, were analyzed. All lung cancer blood samples analyzed in this study were collected before anti-tumor chemotherapy treatment or surgery. For negative controls, three blood samples from healthy donors with non-neoplastic disease were used. The Scientific Committee of University Hospital-UFRJ, Brazil and DanaFarber Cancer Institute, Boston, MA approved this investigation.

\section{RNA Preparation and DD}

Three milliliters of venous blood was obtained with a standard venipuncture technique using anticoagulant. Whole blood was centrifuged at $1800 \times g$ for $40 \mathrm{~min}$ in a clinical centrifuge. The cells present in the buffy coat were collected and washed with $1 \mathrm{ml}$ of buffer containing $10 \mathrm{mM}$ Tris- $\mathrm{HCl}, \mathrm{pH} 7.6,5 \mathrm{mM} \mathrm{MgCl}_{2}$, and $10 \mathrm{mM} \mathrm{NaCl}$. They were centrifuged at $1800 \times$ $g$ for $1 \mathrm{~min}$ and this step was repeated three times. The pellet containing nucleated cells was incubated for $5 \mathrm{~min}$ with $1 \mathrm{ml}$ of Holmes Boner buffer (11). RNA was extracted with phenol:chloroform (1:1), pH 6.0 (11). The pellet containing RNA was resuspended in $300 \mu \mathrm{l}$ of sterile water, and DNAse I treated in TE
Table 1. Primer sequences

\begin{tabular}{cl}
\hline Anchor & LHT11G: 5'-TGCCGAAGCT11G \\
primers & LHT11A: 5'-TGCCGAAGCT11A \\
& LHT11C: 5'-TGCCGAAGCT11C \\
Arbitrary & OPA2: 5'-CGTGAATTCGTGCCGAGCTG \\
primers & OPA4: 5'-TGCCGAAGCTTAATCGGGCTG
\end{tabular}

buffer, $\mathrm{pH} 7.5$, containing $100 \mathrm{mM} \mathrm{MgCl}_{2}$ and $10 \mathrm{mM}$ DTT, and $40 \mathrm{U}$ RNAse inhibitor (12). DD was performed using the RNA Image ${ }^{\circledR}$ kit (GenHunter Corp., Nashville, TN). Table 1 describes sequences of primers not included in the GenHunter kit $(13,14)$. Polymerase chain reaction (PCR)-amplified cDNA products were resolved on a $6 \%$ DNA sequencing gel (Genomyx Corp., Foster City, CA). The bands of interest were excised from the gel $(10,14,15)$.

\section{PCR and Direct Sequencing}

PCR reactions of isolated CDNA fragments were performed with $2.5 \mathrm{U} / \mu \mathrm{l}$ AmpliTaq DNA polymerase (Perkin Elmer, Branchburg, NJ), $100 \mathrm{mM}$ Tris- $\mathrm{HCl}, \mathrm{pH} 8.3,500 \mathrm{mM} \mathrm{KCl}, 1.5 \mathrm{mM} \mathrm{MgCl}_{2}$, and $250 \mu \mathrm{M}$ each of dNTP and $50 \mathrm{nM}$ of each primer in $50 \mu \mathrm{l}$ reaction mix. The PCR reaction was programmed as follows: $95^{\circ} \mathrm{C}$ for $36 \mathrm{sec}$, $53^{\circ} \mathrm{C}$ for $36 \mathrm{sec}, 72^{\circ} \mathrm{C}$ for $90 \mathrm{sec}$ for 35 cycles; elongation was at $72^{\circ} \mathrm{C}$ for $5 \mathrm{~min}$, and refrigeration at $4^{\circ} \mathrm{C}$. A second round of the PCR reaction was performed when necessary. The PCR products of cDNA fragments observed were mostly single bands (data not shown). The nucleotide sequences of cDNA fragments were determined using the Circum Vent Sequencing Kit (New England BioLabs, Beverly, MA) with $\left[\gamma^{-32} \mathrm{P}\right]$ rATP $5^{\prime}$ end-labeled primers, as described in the supplier's instructions. The DNA template was purified from an agarose gel (QIAquick). The samples were run on a $6 \%$ polyacrylamide gel (Genomyx) at $60^{\circ} \mathrm{C}, 3000 \mathrm{~V}, 125 \mathrm{~W}$ and/or sequenced using AmpliTaq ${ }^{\circledR}$ DNA polymerase, FS dye-terminator, modified from Applied Biosystems by the Molecular Biology Core Facility, Dana-Farber Cancer Institute.

\section{RT-PCR and Northern Blot}

The reverse-transcription (RT) reaction was performed with Superscript II per the manufacturer's instructions (Gibco-BRL, Life Technologies, Gaith- 


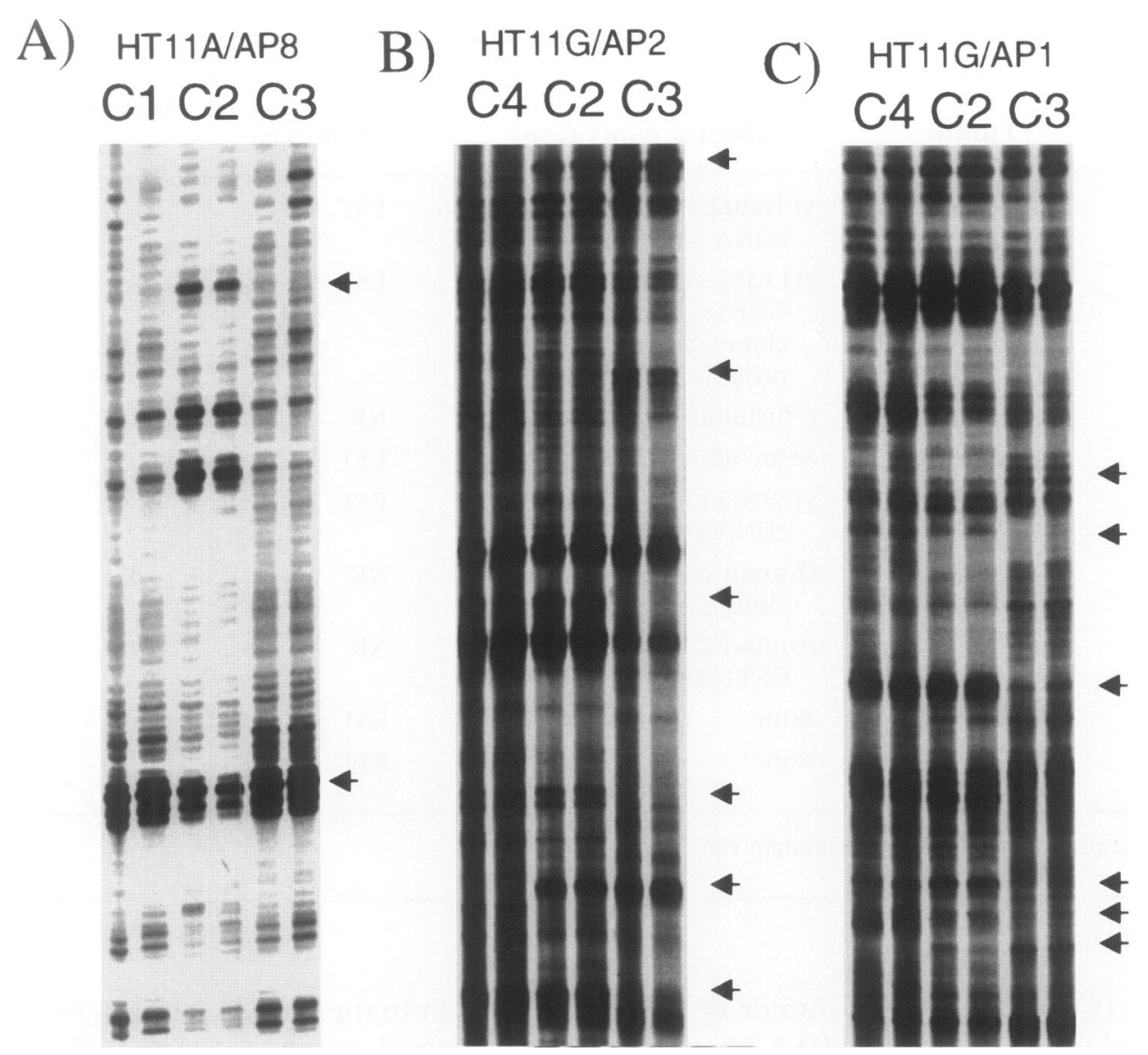

Fig. 1. Individual variation among donor blood RNA samples compared by DD. RNA from tumor-free donor blood samples C1-C4 were compared in duplicate by DD using RNA Image kit primer sets (A) HT11A/AP8, (B) HT11G/AP2, and (C) HT11G/AP1. Arrows show bands differentially expressed among samples.

ersburg, MD). The AB-1 gene was amplified using primers 5' CTCTGGAAGGTCAAGTTACATCATC 3' and 5' AGAGTTTCATTCTGTCGCCCAGGC 3'. Radioactive PCR reactions for probe preparations were performed with $2.5 \mathrm{U} / \mu \mathrm{l}$ AmpliTaq (Perkin Elmer), $100 \mathrm{mM}$ Tris- $\mathrm{HCl}, \mathrm{pH} 8.3,500 \mathrm{mM} \mathrm{KCl}$, $1.5 \mathrm{mM} \mathrm{MgCl}{ }_{2}$, and $200 \mu \mathrm{M}$ each of dNTP, $50 \mathrm{~nm}$ of each primer, and $2.5 \mu \mathrm{l}$ of $\left[\alpha^{32} \mathrm{P}\right] \mathrm{dCTP}(3000$ $\mathrm{Ci} / \mathrm{mmol}$ ) in $50 \mu \mathrm{l}$ reaction mix. The PCR reaction was programmed as follows: initial denaturation was at $94^{\circ} \mathrm{C}$ for $5 \mathrm{~min}$, then $94^{\circ} \mathrm{C}$ for $1 \mathrm{~min}, 53^{\circ} \mathrm{C}$ for $1 \mathrm{~min}, 72^{\circ} \mathrm{C}$ for $1 \mathrm{~min}$ for 35 cycles; elongation was at $72^{\circ} \mathrm{C}$ for $5 \mathrm{~min}$, and refrigeration at $4^{\circ} \mathrm{C}$. Northern blots were performed with Express$\mathrm{Hyb}^{\mathrm{TM}}$ hybridization solution following the manufacturer's instructions (Clontech Laboratories, Palo Alto, CA). Densitometry analysis using Model GS700 Imaging Densitometer (Bio-Rad Laboratories, Hercules, CA) and standard normalization procedures were performed to determine mRNA relative expression.

\section{Results and Discussion}

The gene expression pattern variation between individual samples must not distort the ability of DD to distinguish genes related to metastasis. To test the extent of individual variation between individual blood samples by DD, mRNA from blood of control donors were compared. The variability between control donors differed depending on the primer combination used. Figure 1A shows one of the primer sets that resulted in very few differences among controls, as indicated by arrows, which should have little effect on masking genes marking metastatic tumors. Tremendous variations in cDNA pattern among controls were observed using the anchor primer HTl $1 \mathrm{G}$ as indicated by the arrows in Figure $\mathrm{IB}$ and $\mathrm{C}$. Thus, the primer combinations that generated extended variability, such as HT1 1G, were not used for the subsequent DD experiments.

A limit dilution analysis to determine the 
Table 2. Potential unique markers for solid tumor dissemination in blood

\begin{tabular}{|c|c|c|c|c|c|}
\hline cDNA & Tumor & Homologous Gene & Database & $\begin{array}{c}\text { Identities } \\
(\%)\end{array}$ & $\begin{array}{l}\text { GenBank } \\
\text { (ID) }\end{array}$ \\
\hline $104 \mathrm{bl}$ & $\begin{array}{l}\text { Lung, breast, } \\
\text { colon }\end{array}$ & $\begin{array}{l}\text { ycl8d02.sl Homo sapiens } \\
\text { cDNA clone }\end{array}$ & EST & 94 & T70191 \\
\hline $104 \mathrm{~b} 2(\mathrm{AB}-1)$ & Lung, breast & $\begin{array}{l}\text { ztl3ql l.sl NCI CGAP- } \\
\text { GCBl Homo sapiens cDNA } \\
\text { clone: similar to Al } \\
\text { protein }\end{array}$ & EST & 97 & AA282294 \\
\hline $104 \mathrm{~b} 4$ & Lung, breast & L-histidine decarboxylase & NR & 94 & D 16583 \\
\hline $104 \mathrm{~b} 9(\mathrm{AB}-1)$ & Lung, breast & Same above: $104 \mathrm{~b} 2$ & EST & 97 & AA282294 \\
\hline $110 \mathrm{bl}$ & Lung, breast & $\begin{array}{l}\text { yj09e05.rl Homo sapiens } \\
\text { cDNA clone }\end{array}$ & EST & 100 & H13749 \\
\hline GP1 & $\begin{array}{l}\text { Lung, breast, } \\
\text { colon }\end{array}$ & $\begin{array}{l}\text { Human chromosome } 10 \\
\text { clone LAlONC01 }\end{array}$ & NR & 87 & U82212 \\
\hline $\mathrm{Ll}$ & Lung & $\begin{array}{l}\text { Human BAC clone } \\
\text { GS1 13D04 }\end{array}$ & NR & 98 & AC002087 \\
\hline $\mathrm{Bl}$ & Breast & None & EST and NR & - & - \\
\hline B2 & Breast & None & EST and NR & - & - \\
\hline
\end{tabular}

EST, expressed sequence tags; NR, nonredundant GenBank.

sensitivity of DD to detect a few tumor cells in blood was performed. A 200-bp cDNA fragment specific to HeLa cells displayed differential expression in a $3-\mathrm{ml}$ blood sample to which only $100 \mathrm{HeLa}$ cells were added (data not shown).

To begin identifying metastatic genes, the RNA of two individual control donor blood samples, representing the greatest variation between individuals, and up to five metastatic cancer patient blood samples were compared by DD. As potential markers, we considered RNA up-regulated in at least two patient blood samples and low or absent in normal blood samples. Differentially expressed cDNA fragments of interest were isolated and reamplified by PCR using DD primer (14). A total of 15 up-regulated bands identified by this strategy were isolated. Five of these were overexpressed in blood samples from lung and breast cancer and were considered candidates for general molecular markers for tumor dissemination (Table 2). One of the bands was also detected in the blood sample of a colon cancer case.

Figure 2A shows a comparison of blood from tumor-free donors with that from two metastatic lung cancer patients, $\mathrm{Pl}$ and $\mathrm{P} 2$, respectively. A cDNA fragment differentially expressed in patient blood denominated AB-1 (Apoptosis in $B$ lood-1) that bears $95 \%$ homology with a gene similar to the human Al protein in a database of expressed sequences tags (EST) was identified (GenBank ID AA282294). Human Al protein is a member of the bcl-2 family, described as an apoptotic suppressor (16). The identification of an apoptosis inhibitor homologue gene in blood from patients with metastatic tumors might be correlated with the capability of solid tumor cells to survive in peripheral blood.

In an attempt to identify tumor-specific metastatic markers, we next analyzed a pool containing RNA from blood of four individual normal donors (CP) compared with pools of RNA from blood of three metastatic lung cancer patients (LP) and two metastatic breast cancer patients (BP) (Fig. 2B). The comparison of these samples by DD identified one lung-specific gene (L1), two breast-specific genes (B1 and B2), and one general gene (GPI). The comparison of the control donor pool (CP) with a pool of metastatic tumor blood RNA consisting of LP, BP, and one metastatic colon cancer blood sample by DD generated very few differences in cDNA pattern and was not a useful strategy for investigation of general molecular markers (data not shown).

Table 2 summarizes the results of GenBank analysis of nine cDNA fragments of interest. We required that a match include $95 \%$ identical bases over a stretch of at least 30 bases. The two 
A) HT11A/AP1

C1 C2 P1 P2

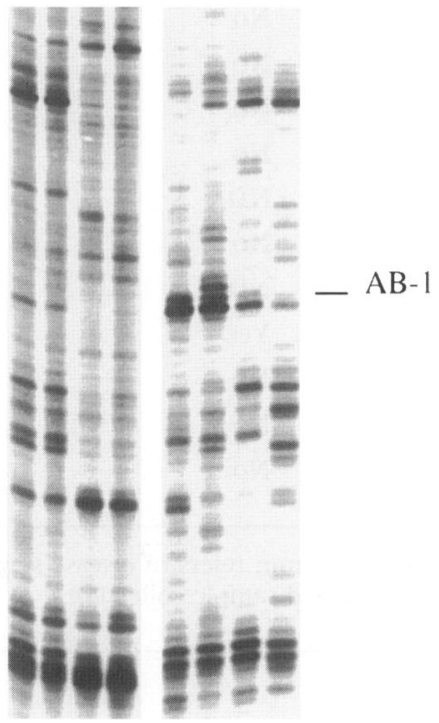

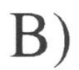

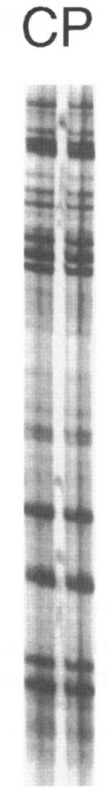

LHT11G/OPA4

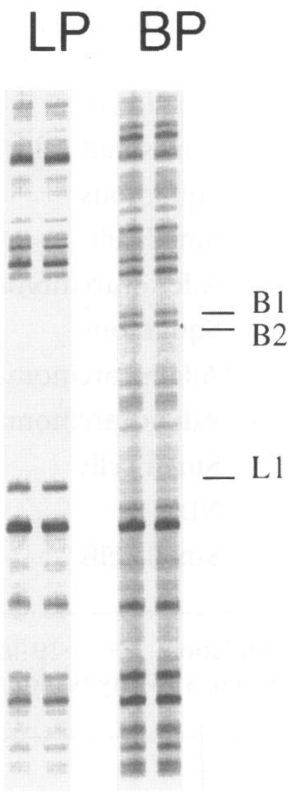

Fig. 2. Identification of potential metastatic markers in peripheral blood samples by DD. Sections of DD gel demonstrating differential expression of $\mathrm{AB}-\mathrm{l}, \mathrm{Ll}, \mathrm{Bl}$, and $\mathrm{B} 2$ cDNAs in patient blood samples. (A) DD using RNA Image kit primer set HTI I A/APl. Individual control blood RNA samples (C1, C2) were compared with individual blood RNA samples of metastatic cancer patients (P1, P2). (B) DD using long primer set LHTllG/ OPA4 (Table 1). Comparison of tumor-free blood RNA pool (CP) with a metastatic lung cancer blood RNA pool (LP) and a metastatic breast cancer blood RNA pool (BP).

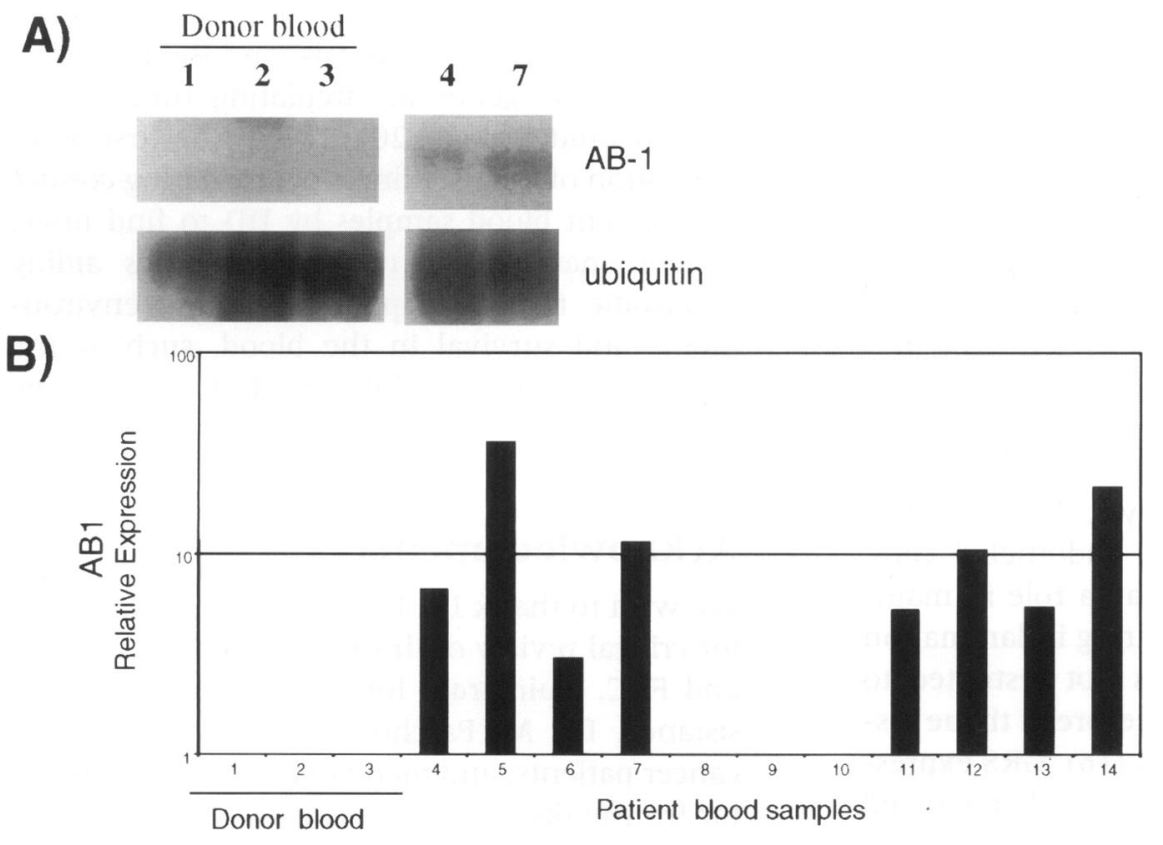

Fig. 3. Expression of AB-1 mRNA in blood of solid tumor patient. (A) Northern blot analysis confirming the low expression of $\mathrm{AB}-1$ in tumor-free donor blood samples (lanes 1-3) versus cancer patient blood samples (lanes 4 and 7 ). The blot was stripped and reprobed with ubiquitin for normalization. (B) Quantitative representation of Northern blot analysis of tumorfree donor blood samples (lanes 1-3) and 11 tumor patient blood samples (lanes 4-14). fragments specific for metastatic breast cancer blood samples had the same sequence but did not match with any EST sequence. With the exception of $\mathrm{AB}-1$ and a CDNA fragment that is partially similar to the human gene for L-histidine decarboxylase, the remaining fragments analyzed were unknown genes.

To confirm DD data showing the presence of $\mathrm{AB}-1$ in patient blood but not in tumor-free do- nor blood samples, Northern blot analyses were conducted on this gene. Figure $3 \mathrm{~A}$ shows that AB-1 was not expressed in three tumor-free donor blood samples. AB-1 was up-regulated in $72 \%$ of cancer patient blood samples tested (Fig. 3B). More than 10-fold overexpression was observed in four out of eight metastatic cancer blood samples (Fig. 3B, lanes 5, 7, 12, and 14). Three of them were cases of small-cell lung can- 
Table 3. Patient background

\begin{tabular}{|c|c|c|c|c|c|}
\hline Sample Number & Tumor & Histology & Metastatic & Treatment & AB-1 RNA \\
\hline 4 & Lung & Small cells & No & No & + \\
\hline 5 & Lung & Non-small cells & Yes & No & ++ \\
\hline 6 & Lung & Squamous & No & No & + \\
\hline 7 & Lung & Small cells & Yes & No & ++ \\
\hline 8 & Colon & Adenocarcinoma & Yes & ND & - \\
\hline 9 & Lung & Squamous & Yes & No & - \\
\hline 10 & Colon & Adenocarcinoma & Yes & ND & - \\
\hline 11 & Breast & Adenocarcinoma & Yes & Yes & + \\
\hline 12 & Lung & Small cells & Yes & No & ++ \\
\hline 13 & Lung & ND & ND & No & + \\
\hline 14 & Lung & Small cells & Yes & No & ++ \\
\hline
\end{tabular}

$\mathrm{ND}$, not determined;,$+ 1-$ to 10 -fold up-regulation;,$++>10$-fold up-regulation. Metastatic column refers to disease stage at the time of blood collection. Treatment column refers to any tumor treatment or surgery before blood sample collection.

cer carcinoma (SCLC), which is a very aggressive and metastatic form of lung cancer (17). Whether AB-1 is correlated with tumor prognosis is still unknown. Table 3 describes patient information. The poor detection of $\mathrm{AB}-1$ in donor blood samples suggests that the $A B-1$ gene may be correlated with solid-tumor cell survival in peripheral blood. More investigation is needed to evaluate the application of this gene as a molecular marker for metastatic cancers.

The AB-1 gene is highly homologous to the human Al gene as well as to GRS and Bfl-1 cDNA. Human Al is induced by IL- $1 \beta$ and tumor necrosis factor $\alpha$ (TNF- $\alpha$ ) in endothelial cells, which suggests that it may play a role in maintaining endothelial survival during inflammation (18). However, human Al is not restricted to endothelial cells and has a widespread tissue distribution, including leukocytes (16). GRS expression in normal human tissues is largely restricted to the hematopoietic compartment as well as in hematopoietic malignancies and melanoma cell lines (19). Our data support that AB-1, in contrast with its homologues Al and GRS, is not expressed in normal leukocytes and is present in blood samples from solid-tumor patients.

Efforts in metastasis research have centered on the phenotypic and genetic differences between primary site and metastatic site tumors. They focus on differences in angiogenesis, signal transduction pathways, cell communication, migration, and adhesion. However, genes that could be used as molecular markers of tumor dissemination and metastasis, and the biological role of these genes in circulating tumor cells, remain unidentified (20). This is the first demonstration of the usefulness of comparing control and patient blood samples by DD to find novel genetic markers for metastasis. Genes aiding metastatic tumor adaptation to new environments and survival in the blood, such as the potential apoptotic inhibitor AB-1, need to be further characterized for clinical use.

\section{Acknowledgments}

We wish to thank Dr. P. Liang and Dr. K. Martin for critical review of this manuscript, J. A. Teece and F. C. Guimaraes for excellent technical assistance, Dr. M. Paschoal for selection of lung cancer patients, and members of our laboratories for fruitful discussions. This work was supported by grant RO-1-CA61253 from the National Institute of Health and CAPES (Graduate Education Federal Agency). This work received an AACRPharMingen Young Investigator Award at the 90th Annual Meeting of American Association for Cancer Research, 1999.

\section{References}

1. Jonhson PWM, Burchill SA, Selby PJ. (1995) The molecular detection of circulating tumor cells. Br. J. Cancer 72: 268-276. 
2. Glaves D. (1983) Correlation between circulating cancer cells and incidence of metastasis. $\mathrm{Br} . \mathrm{J}$. Cancer 48: 665-673.

3. Weiss L. (1992) Biomechanical interactions of cancer cells with the microvasculature during hematogenous metastasis. Cancer Metastasis Rev. 11: 227-235.

4. Hanna N, Fidler IJ. (1980) The role of natural killer cells in the destruction of circulating tumor emboli. J. Natl. Cancer Inst. 65: 801-809.

5. Fidler IJ. (1985) Macrophages and metastasis: a biological approach to cancer therapy: presidential address. Cancer Res. 45: 4714-4726.

6. Stuehr DJ, Nathan CF. (1989) Nitric oxide, a macrophage product responsible for cytostasis and respiratory inhibition in tumor target cells. J. Exp. Med. 169: 1543-1555.

7. Dong Z, Staroselsky AH, Zi X, Xie K, Fidler IJ. (1994) Inverse correlation between expression of inducible nitric oxide synthase activity and production of metastasis in K-1735 murine melanoma cells. Cancer Res. 54: 789-793.

8. Xie K, Huang S, Dong Z, et al. (1995) Transfection with the inducible nitric oxide synthase gene suppresses tumorigenicity and abogrates metastasis in K-1735 murine melanoma cells. J. Exp. Med. 181: 1333-1343.

9. Liotta LA, Kleinerman J, Saidel GM. (1976) The significance of hematogenous tumor cell clumps in the metastatic process. Cancer Res. 36: 889-894.

10. Liang P, Pardee AB. (1992) Differential display of eukaryotic messenger RNA by means of the polymerase chain reaction. Science 257: 967-971.

11. Sambrook J, Fritsch EF, Maniatis T. (1989) Extraction and purification of RNA. In: Molecular Cloning, A Laboratory Manual, 2nd ed. Cold Spring Harbor Laboratory Press, Cold Spring Harbor, New York, p. 7.3.
12. Ausubel FA. (1996) Preparation and analysis of RNA. In: Ausubel FA, Brent RE, Kingston DD, et al. (eds). Current Protocols in Molecular Biology, 2nd edition. John Wiley and Sons, New York, p. 4.

13. Zhao S, Ooi SL, Pardee AB. (1995) New primer strategy improves precision of differential display. Biotechniques 18: 842-846.

14. Martin KJ, Pardee AB. (1999) The principles of differential display. In: Weissman SM (ed.) $c D N A$ Preparation and Analysis. Methods in Enzymology, Vol 303, pp. 234-258.

15. Liang P, Averboukh L, Pardee AB. (1993) Distribution and cloning of eukaryotic mRNAs by means of differential display: refinements and optimization. Nucl. Acids Res. 21: 3269-3275.

16. Karsan A, Yee E, Kaushansky K, Harlan JM. (1996) Cloning of a human Bcl-2 homologue: inflammatory cytokines induce human $\mathrm{Al}$ in cultured endothelial cells. Blood 87: 3089-3096.

17. Nesbitt JC, Lee JS, Komaki R, Roth JA. (1997) Neoplasms of the thorax. In: Holland JF (ed). Cancer Medicine, 4th ed., Williams and Wilkins, Philadelphia, Pennsylvania, pp. 1723-1804.

18. Karsan A, Yee E, Harlan JM. (1996) Endothelial cell death induced by tumor necrosis factor- $\alpha$ is inhibited by the bcl-2 family member, Al. J. Biol. Chem. 271: 27201-27204.

19. Kenny JJ, Knobloch TJ, Augustus M, Carter KC, Rosen CA, Long JC. (1997) GRS, a novel member of the $\mathrm{Bcl}-2$ gene family, is highly expressed in multiple cancer cell lines and in normal leukocytes. Oncogene 14: 997-1001.

20. Raj GV, Moreno JG, Gomella LG. (1998) Utilization of polymerase chain reaction technology in the detection of solid tumors. Cancer 82: 14191442. 